\title{
Hydrogeochemical Characterization of the Dissolved Load of the Major Elements Downstream of the Watershed of the Wadi Sebou, Morocco
}

\author{
Eudes Yoli Baudet Bahin, Souad Haida \\ Department of Geology, Faculty of Sciences, Geosciences and Natural Resources (GNR) Ibn Tofail University, University Campus, \\ Kenitra, Morocco \\ Email: eudesbahin@yahoo.fr
}

How to cite this paper: Bahin, E.Y.B. and Haida, S. (2018) Hydrogeochemical Characterization of the Dissolved Load of the Major Elements Downstream of the Watershed of the Wadi Sebou, Morocco. Journal of Geoscience and Environment Protection, 6, 159-177.

https://doi.org/10.4236/gep.2018.67011

Received: April 27, 2018

Accepted: July 28, 2018

Published: July 31, 2018

Copyright $\odot 2018$ by authors and Scientific Research Publishing Inc. This work is licensed under the Creative Commons Attribution International License (CC BY 4.0).

http://creativecommons.org/licenses/by/4.0/

cc) (i) Open Access

\begin{abstract}
The aim of this paper was to analyse the dissolved elements in water which were sampled from the Sebou River in Northern Morocco. The sampling was conducted at the Mechra Bel station for two different hydrological cycles (2013/2013 and 2013/2014). The study was to determine the type of water facies present in the area. The piper diagram shows that the dominant water facies in the area are that of Nacl water facies, which contribute to $56 \%$ of the total amount of major elements in the water. The study also revealed that during high water levels, there is dilution of water and during low water levels, the concentration of elements increases. The presence of halite and gypsum bearing rocks in the study area gives an indication that the supply of $\mathrm{Na}^{+}$and $\mathrm{Cl}^{-}$is related to the dissolution of evaporates. The results also revealed that the specific export of the dissolved load amounts to $127.6 \mathrm{t} / \mathrm{km}^{2} /$ year. Finally, the quantification of the dissolved load, through the determination of dissolved material flows shows that the specific export of material amounts to 127.6 $\mathrm{t} / \mathrm{km}^{2} /$ year.
\end{abstract}

\section{Keywords}

Sebou Basin, Dissolved Transport, Seasonal Variations, Dissolved Flux

\section{Introduction}

Rivers play an important role in the transportation of dissolved and solid materials from the mechanical and chemical erosion of continental rocks to the oceans (Livingstone, 1963; Meybeck, 1976; Berner and Berner, 1996) [1] [2] [3]. 
Dissolved fluvial transport also plays a major role in the overall cycle of nutrients essential for maintaining primary marine productivity (e.g. Jickells, 1998; Holland H.D., 2005) [4] [5].

These dissolved elements carried by the continental waters can serve as tracers to apprehend the functioning of the fluvial systems. They are influenced by rainfall (Corbonnois, 1996) [6], flows (Dupraz, 1984; Meybeck, 1985) [7] [8], as well as by the conditions of surface, sub-surface or subterranean water flow (Kattan, 1989; Bakalowicz, 1995) [9] [10]. The problem of the chemical composition of the various rivers and the factors of its variation has always been of interest to hydrologists and geochemists working on the rivers, in particular to quantify the importance of chemical erosion and the loss of materials that are evacuated each year in soluble form from the continent to the oceans. The low intensity chemical weathering phenomena in semi-arid climates are inherent in the very strong seasonal contrast of precipitation between the dry and wet periods. It is therefore interesting to be able to highlight the effects of climatic variations on chemical weathering processes and to assess whether there is an impact related to the construction of dams on water quality. The Sebou watershed, subject to strong anthropic pressure linked to the hydraulic installations that are constantly increasing under the effect of climate change, is a good example for the monitoring of climatic and anthropogenic influences on the geochemical quality of the solid and dissolved flux.

In fact, this Sebou watershed has already been the subject of studies concerning particulate and dissolved transport as well as the reports of mechanical and chemical erosion by Haida (2000) [11], and the resumption of dissolved flux will allow a better appreciation of effects caused by the construction of the Al Wahda dam on Ouerrha one of its main tributaries and climatic variations on the quality of surface waters.

Wadi Sebou is also a source of water for domestic, agricultural and industrial use for the populations of the basin and it is subject to contamination of different orders (ABHS, 2011) [12]. Water pollution has reached critical levels and that affects the economic and social development of the basin (ABHS, 2011).

\section{Area of Study}

The Sebou watershed (Figure 1) covers an area of $40,000 \mathrm{~km}^{2}$ in northwestern Morocco, between meridians $4^{\circ}$ and $7^{\circ}$ West and parallels $33^{\circ}$ and $35^{\circ}$ North. It is part of the morphogenetic domain of alpine age and is in the form of a basin, between the Rif massif in the North rising to 2450, the iddle Atlas chain and the Meseta to the South, the corridor Fez-Taza in the East and the Atlantic Ocean in the West. It is open to the West on the Atlantic Ocean, to the North near the Mediterranean and to the Southeast is dominated by an arid depression. Its climate is of Mediterranean type with Atlantic, Mediterranean and continental Saharan influence.

The Sebou watershed has a large lithological diversity at the outcrop. The 


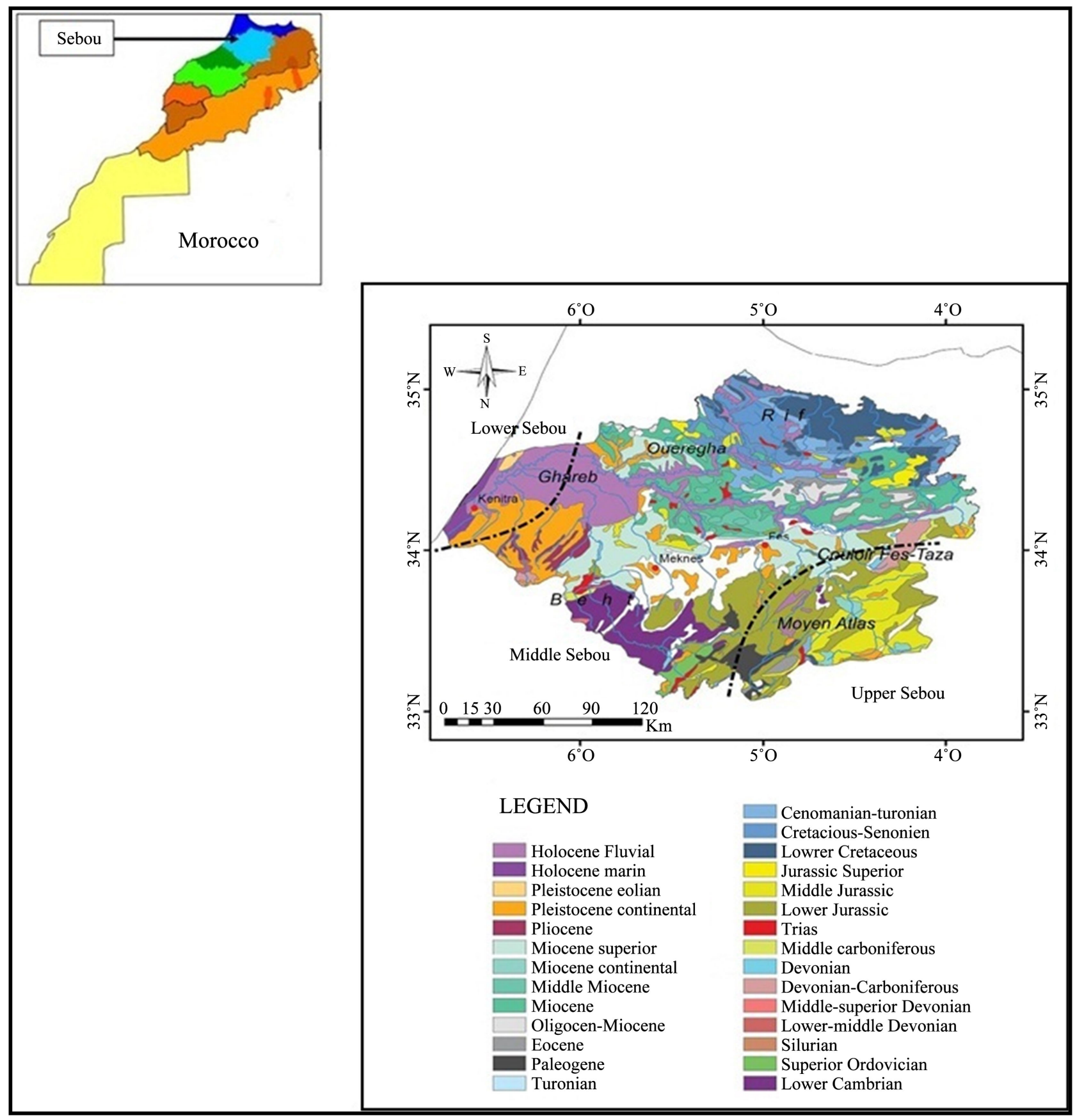

Figure 1. Simplified geological map of the Sebou basin and its location in Morocco (Geologic Service of Morocco, 1985, modified).

main lithological formations whose areas are very important or whose characteristics will play a major role in the erosion process are:

- The limestone and dolomitic formations of the Lias, affected by an intense karst erosion which characterizes the upstream part of the basin (Middle Atlas).

- The basaltic formations resulting from intense volcanic activity during the Quaternary that appear in the Middle Atlas. 
- In the South Rifain strait, there are marly and sandstone formations of Cretaceous and Tertiary age overlying Miocene limestone formations.

- Evaporitic formations corresponding to the salifera and gypsum Triassic diapirs pierce the cover in the Prérif especially at Jbel Tissa and Jorf El Melh.

- In the Gharb plain, alluvia consist of thick Miocene-rich clay-sandy fluviomarine sediments, covered with fine deposits from the Sebou and its tributaries during the Quaternary period (Combe, 1969, 1975; ORMVAG, 1997) [13] [14] [15].

The average annual rainfall in the Sebou watershed is about $640 \mathrm{~mm}$. It decreases away from the sea towards the Beht valleys and on the upper Sebou with an average of 400 to $550 \mathrm{~mm}$, and increases rapidly on the slopes of the Rif reaching a maximum of 1000 to $1500 \mathrm{~mm}$ /year.

The Oued Sebou has a total length of $614 \mathrm{~km}$ from its source, it collects from its upstream the waters of the Rifaine (Oued Ouerrha) and those of the ridges (Oued Guigou, Oued Zlouh, Oued Mikkés), and Oued Inaouen which comes from the region of Taza where it borders the middle-atlasic and pre-Rifean regions. After crossing the Pre-Rifean hills, the Sebou opens in the plain of Gharb, where it receives the Oued Beht and Oued R'dom to the South. It joins the Atlantic near Kenitra to Mehdia. Its average flow is $137 \mathrm{~m}^{3} / \mathrm{s}$. In winter, the highest average is that of February $\left(350 \mathrm{~m}^{3} / \mathrm{s}\right)$, and the peak flow can reach $6000 \mathrm{~m}^{3} / \mathrm{s}$ during periods of heavy floods.

\section{Data and Methodology}

\subsection{Sampling and Analysis}

The basic data used in this study (Table 1) concerns chemical analysis of major elements and physico-chemical parameters of surface water. These were collected at the Mechra Bel Ksiri station which is the most downstream hydraulic station of the Sebou basin and where the monitoring of liquid flow measurements is carried out by the Sebou Hydraulic Basin Agency (SHBA). During the 2012-2013 and 2013-2014 hydrological cycles, this station conducted bi-monthly or monthly water sampling and measurements of physico-chemical parameters in situ, all year long to detect the effects of seasonal changes on the river's chemical compositions. The water samples are taken in the middle of the stream at a depth of $50 \mathrm{~cm}$, then filtered in the laboratory with millipore filters of $0.45 \mu \mathrm{m}$ porosity and placed in 1 liter polyethylene bottles. A volume of $250 \mathrm{ml}$ of these filtered water samples is sent to the laboratories of the National Center for Scientific and Technical Research (NCSTR) of Rabat for chemical analysis. Temperature, $\mathrm{pH}$, salinity, conductivity, TDS and water depth are measured on site. The water levels are transformed into liquid flows using the calibration curve provided by the Sebou Hydraulic Basin Agency.

The analysis of $\mathrm{SO}_{4}^{2-}, \mathrm{Cl}^{-}$is done by ion chromatography, the major cations $\mathrm{Ca}^{2+}, \mathrm{Mg}^{2+}, \mathrm{Na}^{+}, \mathrm{K}^{+}$by atomic absorption. Since the alkalinity is not measured 
Table 1. Chemical composition of the sebou water at mechra bel ksiri station (meq/l).

\begin{tabular}{|c|c|c|c|c|c|c|c|c|c|c|}
\hline Reference & Dates & $\mathrm{Q}\left(\mathrm{m}^{3} / \mathrm{s}\right)$ & $\mathrm{Ca}^{2+}$ & $\mathrm{Mg}^{2+}$ & $\mathrm{Na}^{-}$ & $\mathrm{K}^{+}$ & $\mathrm{Cl}^{-}$ & $\mathrm{SO}_{4}^{2-}$ & $\mathrm{HCO}_{3}^{-}$ & $\begin{array}{c}\text { Water level } \\
\text { (m) }\end{array}$ \\
\hline ICP1 & $10 / 07 / 2012$ & 41.3 & 2.766 & 1.643 & 4.565 & 0.151 & 4.400 & 1.634 & 2.342 & 172 \\
\hline ICP2 & $20 / 09 / 2012$ & 36 & 2.522 & 1.572 & 3.900 & 0.129 & 3.641 & 1.443 & 2.197 & 158 \\
\hline ICP3 & $16 / 10 / 2012$ & 6 & 5.265 & 3.299 & 14.921 & 0.429 & 14.878 & 3.126 & 4.758 & 60 \\
\hline ICP4 & $13 / 11 / 2012$ & 34.8 & 4.504 & 2.575 & 9.150 & 0.213 & 10.162 & 2.225 & 3.710 & 155 \\
\hline ICP5 & $04 / 12 / 2012$ & 196.5 & 3.840 & 1.457 & 6.551 & 0.155 & 7.517 & 2.364 & 2.291 & 458 \\
\hline ICP6 & $14 / 01 / 2013$ & 18.5 & 3.258 & 1.997 & 6.650 & 0.187 & 5.342 & 1.960 & 3.410 & 108 \\
\hline ICP7 & $14 / 02 / 2013$ & 262.5 & 2.713 & 1.310 & 3.268 & 0.058 & 3.511 & 1.414 & 1.892 & 533 \\
\hline ICP8 & $05 / 03 / 2013$ & 356 & 2.422 & 1.317 & 4.707 & 0.150 & 4.627 & 1.498 & 1.847 & 626 \\
\hline ICP9 & $26 / 03 / 2013$ & 620 & 2.560 & 1.121 & 5.221 & 0.127 & 4.333 & 1.429 & 2.180 & 890 \\
\hline ICP10 & $16 / 04 / 2013$ & 309.6 & 2.927 & 1.885 & 4.369 & 0.125 & 5.672 & 1.492 & 1.960 & 580 \\
\hline ICP11 & $14 / 05 / 2013$ & 109.8 & 2.908 & 1.405 & 4.511 & 0.162 & 3.529 & 1.533 & 2.832 & 327 \\
\hline ICP12 & $04 / 06 / 2013$ & 83.2 & 3.179 & 1.341 & 4.650 & 0.160 & 4.081 & 1.606 & 2.952 & 273 \\
\hline ICP13 & $18 / 06 / 2013$ & 76.1 & 3.410 & 1.656 & 4.152 & 0.121 & 4.658 & 2.127 & 2.450 & 257 \\
\hline ICP14 & $16 / 07 / 2013$ & 54.5 & 3.267 & 1.474 & 3.294 & 0.104 & 3.880 & 1.800 & 2.220 & 205 \\
\hline ICP15 & $13 / 08 / 2013$ & 48.1 & 3.294 & 1.715 & 3.631 & 0.104 & 4.264 & 2.011 & 2.361 & 189 \\
\hline ICP16 & $03 / 09 / 2013$ & 37.9 & 3.597 & 2.078 & 7.775 & 0.200 & 8.570 & 2.431 & 2.399 & 163 \\
\hline ICP17 & $24 / 09 / 2013$ & 28.7 & 4.736 & 2.292 & 10.116 & 0.216 & 10.765 & 2.927 & 3.486 & 138 \\
\hline ICP18 & $08 / 10 / 2013$ & 13.1 & 6.095 & 3.552 & 16.455 & 0.370 & 17.862 & 3.894 & 4.666 & 90 \\
\hline ICP19 & $29 / 10 / 2013$ & 16.6 & 3.872 & 1.797 & 2.153 & 0.232 & 2.963 & 1.768 & 2.166 & 102 \\
\hline ICP20 & $12 / 11 / 2013$ & 92.6 & 3.666 & 1.272 & 5.387 & 0.185 & 6.220 & 1.897 & 2.179 & 293 \\
\hline ICP21 & $26 / 11 / 2013$ & 20.7 & 4.631 & 1.650 & 6.823 & 0.161 & 7.509 & 2.434 & 2.783 & 115 \\
\hline ICP22 & $10 / 12 / 2013$ & 108.3 & 4.639 & 1.642 & 6.006 & 0.206 & 6.442 & 1.868 & 2.958 & 324 \\
\hline ICP23 & $19 / 12 / 2013$ & 205.5 & 4.052 & 1.580 & 6.464 & 0.114 & 6.497 & 2.552 & 2.949 & 469 \\
\hline ICP24 & $07 / 01 / 2014$ & 57.5 & 4.916 & 2.332 & 11.666 & 0.354 & 12.208 & 2.741 & 3.687 & 213 \\
\hline ICP25 & $28 / 01 / 2014$ & 430 & 4.393 & 1.243 & 6.839 & 0.124 & 6.619 & 2.196 & 2.620 & 689 \\
\hline ICP26 & $11 / 02 / 2014$ & 330 & 3.804 & 1.326 & 4.726 & 0.134 & 4.548 & 1.836 & 2.817 & 600 \\
\hline ICP27 & $25 / 02 / 2014$ & 251.1 & 3.535 & 1.414 & 4.696 & 0.106 & 4.864 & 1.897 & 2.511 & 521 \\
\hline ICP28 & $11 / 03 / 2014$ & 348 & 3.492 & 1.453 & 4.562 & 0.113 & 4.608 & 1.929 & 2.539 & 618 \\
\hline ICP29 & $25 / 03 / 2014$ & 535 & 3.519 & 1.252 & 3.428 & 0.086 & 3.584 & 1.566 & 2.441 & 805 \\
\hline ICP30 & $08 / 04 / 2014$ & 510 & 4.093 & 1.424 & 5.288 & 0.115 & 5.384 & 1.853 & 2.907 & 780 \\
\hline ICP31 & $29 / 04 / 2014$ & 333 & 3.407 & 1.313 & 3.511 & 0.082 & 4.117 & 1.785 & 2.177 & 603 \\
\hline ICP32 & $13 / 05 / 2014$ & 153.7 & 3.237 & 1.524 & 4.014 & 0.117 & 4.546 & 1.909 & 2.237 & 401 \\
\hline ICP33 & $27 / 05 / 2014$ & 110.4 & 3.366 & 1.566 & 4.473 & 0.148 & 5.095 & 1.861 & 2.301 & 328 \\
\hline ICP34 & $10 / 06 / 2014$ & 80.5 & 3.714 & 1.497 & 3.237 & 0.087 & 3.814 & 1.765 & 2.534 & 267 \\
\hline ICP35 & $24 / 06 / 2014$ & 69.6 & 3.601 & 1.663 & 3.972 & 0.122 & 4.822 & 2.081 & 2.418 & 242 \\
\hline ICP36 & $08 / 07 / 2014$ & 45.7 & 3.889 & 1.882 & 4.477 & 0.144 & 4.540 & 1.939 & 3.139 & 183 \\
\hline
\end{tabular}


in the laboratory, we have estimated it from cations and anions, based on the principle of electroneutrality and assuming that there has been no anionic or cationic deficiency, that is to say that the main anions and cations were dosed $(\Sigma$ Cations meq $/ \mathrm{L}=\Sigma$ Anions meq/L). The validity of the chemical analysis was carried out by the calculation of the ionic balance. The errors of the analysis when the concentrations are measured are lower than $\pm 5 \%$.

\subsection{Demonstration of the Mineralization}

The dissolution of a mineral in water can be described by a state of equilibrium: when the water is in contact with a mineral, the concentration of the solution increases to reach a maximum for some given physicochemical conditions.

It is said that the solution is saturated with this mineral. The saturation state is expressed by the saturation index (CIDU et al., 2009) [16]:

$$
\text { Is }=\log (K)-\log (P I)
$$

with $K$ as the constant of the equilibrium and $P I$ the ionic product.

Three cases are possible:

Is $<0$ means under saturation of a solution with respect to a mineral;

$I s=0$ indicates a state of saturation;

Is $>0$ demonstrates a supersaturation.

In our study, the saturation indices for the minerals (halite, gypsum, sylvite, calcite, dolomite and aragonite) and the chemical equilibria were calculated using the PhreeqC program (PARKHURST et al., 1999) [17].

\subsection{Concentration or Dilution Factor}

The factor of concentration or dilution of ions $[\mathrm{rN}]$ between two hydrological periods makes it possible to highlight the geochemical behavior of these ions during hydrological cycles. This factor corresponds to the concentration ratio $[\mathrm{N}]$ of the chemical element $\mathrm{N}(\mathrm{meq} / \mathrm{l})$ in flood and in water-weighted by the total dissolved charge (TD).

Thus: $\mathrm{rN}=([\mathrm{N}] /[\mathrm{TD}])$ raw/([N]/[TD]) low water

If $\mathrm{rN}<1$ there is a dilution in flood

If $\mathrm{rN}>1$ we have a concentration in flood

\subsection{Calculation of Dissolved Material Flows}

To monitor the temporal variation in concentrations and flows, we will try to compare the results obtained for the period of 2012-2014 with the results of monitoring carried out by HAIDA (2000) for the period of 1996-1998. Since changes in the concentration of dissolved elements in river waters are mainly related to fluctuations in the flow of these rivers (MANCZAK and FLORCZYK, 1971, PROBST, 1983, KATTAN, 1989) [18] [19], it is possible to establish relationships, or models of chemical qualities between each dissolved element and the flow. 
The flow is expressed as follows: $\Phi i=C i \times Q i$

Two methods exist to perform the calculation of the flow of suspended matter, stochastic methods based on the use of means and deterministic methods using flow-concentration relationships. In fact, the quantitative and qualitative studies of these inputs make it possible to calculate the denudation rates of continental rocks (Meybeck, 1979; Stallard and Edmond, 1983; Probst, 1990; Amiotte-Suchet, 1995) [20] [21] [22] [23], and others, to characterize the sources of inputs in a watershed (Goldstein and Jacobsen, 1987, Negrel et al., 1993) [24] [25]. Stochastic methods can sometimes overestimate flows for wet cycles, while deterministic methods may underestimate them for dry cycles (Sehmi, 1996) [26].

In the case of our study the calculations were made using the stochastic method, this method permits the calculation for each period $(i)$, the average of the concentrations weighted by flow rates $\left(C_{i m}\right)$, then the flow of dissolved matter which is the product of this concentration $\left(C_{i}\right)$ by the volume of water $\left(Q_{i}\right)$ obtained by integration of the flows for the period $(i)$.

$$
\begin{gathered}
C_{i m}=1 / \sum_{i=1}^{n}\left(Q_{i}\right) \times \sum_{i=1}^{n}\left(C_{i}\right) \times\left(Q_{i}\right) \\
\Phi_{i}=\sum_{i=1}^{n}\left(C_{i m}\right) \times \int_{t_{1}}^{t_{2}} Q d t
\end{gathered}
$$

\section{Results and Discussions}

\subsection{Hydrology}

The Sebou watershed is controlled downstream by the Mechra Bel Ksiri station, which is located after the confluence of the Wadi Ouerrha (its main tributary) and the middle course of Sebou. At this station, the water coming from upstream of Sebou is managed by the Idriss $1^{\text {ier }}$ dam impounded in 1973, and the waters which come from Ouerrha which are governed by the Al Wahda dam impounded in 1996. The Mechra Bel Ksiri station is located upstream of the Gharb flood plain, $90 \%$ of whose flood problems are caused by inputs from Wadi Ouerrha.

Before 1973, the date of impoundment of the Idriss $1^{\text {ier }}$, the average liquid inputs from the Sebou to the Mechra Bel Ksiri station were approximately 5.109 $\mathrm{m}^{3} /$ year. These contributions are slightly different from the combined contributions from Azib Es Soltane station (Middle Sebou) and that of M'jara (Ouerrha), which amount to $5.48109 \mathrm{~m}^{3} /$ year. The difference between these two values can be attributed to water losses between upstream and downstream of the basin and more particularly to the phenomenon of overflow of water during floods. From 1973, the contributions from the Middle Sebou lowered by 55\% (effect of the dam Idriss $\left.1^{\text {ier }}\right)$, only the Ouerrha continues to bring water volumes little different from the previous period (2.03 $109 \mathrm{~m}^{3} /$ year) which accounts for nearly $70 \%$ of the inflows arriving at Mechra Bel Ksiri. With the commissioning of the $\mathrm{Al}$ Wahda dam, the reduction of the liquid inputs of oued Ouerrha can be estimated for the year 1996/1997 to about 60\%, thus in November 1996 about $90 \%$ 
of the volume of water that overflows in the plain could be avoided despite heavy rainfall experienced in this plain in December 1996.

Thus, Bahin's (2017) [27] analysis and characterization of the hydroclimatic variability from the 1960s to 2012 shows that the analysis of the rainfall/discharge relationship highlights the strong regularization of the course regimes in the Sebou watershed overrides the climatic effect.

\subsection{Chemical Facies of Water}

Sebou waters at the Mechra Bel Ksiri station are highly mineralized. The conductivity varies between $712 \mu \mathrm{S} / \mathrm{cm}$ and $2150 \mu \mathrm{S} / \mathrm{cm}$, with an average of 980 $\mu \mathrm{S} / \mathrm{cm}$. It is high during periods of low water and gradually decreases during floods. This high conductivity shows the important dissolution or hydrolysis of the various minerals that come from the rocks sources of the basin. The temperature of the water varies between $11.5^{\circ} \mathrm{C}$ and $18.5^{\circ} \mathrm{C}$ during the high-water period, and between $20.5^{\circ} \mathrm{C}$ and $28.5^{\circ} \mathrm{C}$ during the low water period, with an annual average of $18^{\circ} \mathrm{C}$. The measured $\mathrm{pH}$ is 7.45 in January (flood period) and 8.89 in July (low water period) and indicates the basic character of Sebou waters in Mechra Bel Ksiri throughout the year.

The proportions of anions and cations in Sebou water in Mechra Bel Ksiri (Figure 2) show that chlorides and sodium represent respectively $30 \%$ and $26 \%$ of the total weight of the dissolved elements and make these waters a facies water chlorinated-sodium. The $16 \%$ calcium represents the third most important element. These high levels are explained by the alteration and leaching of evaporite rocks (halite and gypsum) in soils. Bicarbonates (11\%), sulphates (8\%), magnesium $(7 \%)$ and potassium $1 \%$ represent the chemical elements least present in Sebou waters.

Indeed, the order of abundance of the major elements in Sebou waters at Mechra Bel Ksiri is not affected by seasonal or annual variations in flows. It depends mainly on the contribution of the evaporitic and carbonate formations of the basin and the importance of the drainage of the superficial aquifer by the watercourse.

The projection of surface water analysis from Sebou to Mechra Bel Ksiri (Figure 3) on the trilinear diagram of Piper confirms that the water have a sodium chloride facies with a significant amount of calcium. This water is a representative of the alteration effect of evaporite rocks (halite and gypsum).

\subsection{Seasonal Evolution of Water Quality}

An examination of the flow-concentration relationship (Figure 4) for dissolved chemical element provides a better understanding of their origins and behaviors. The set of chemical elements measured downstream from Sebou to Mechra Bel Ksiri show that their concentrations are functions of the flow $\left(C_{r}=C \times Q^{-b}\right)$, with $\mathrm{Cr}$ the total measured concentration of the river, $\mathrm{C}$ the concentration of the element and $\mathrm{Q}$ the flow rate at the time of sampling. 


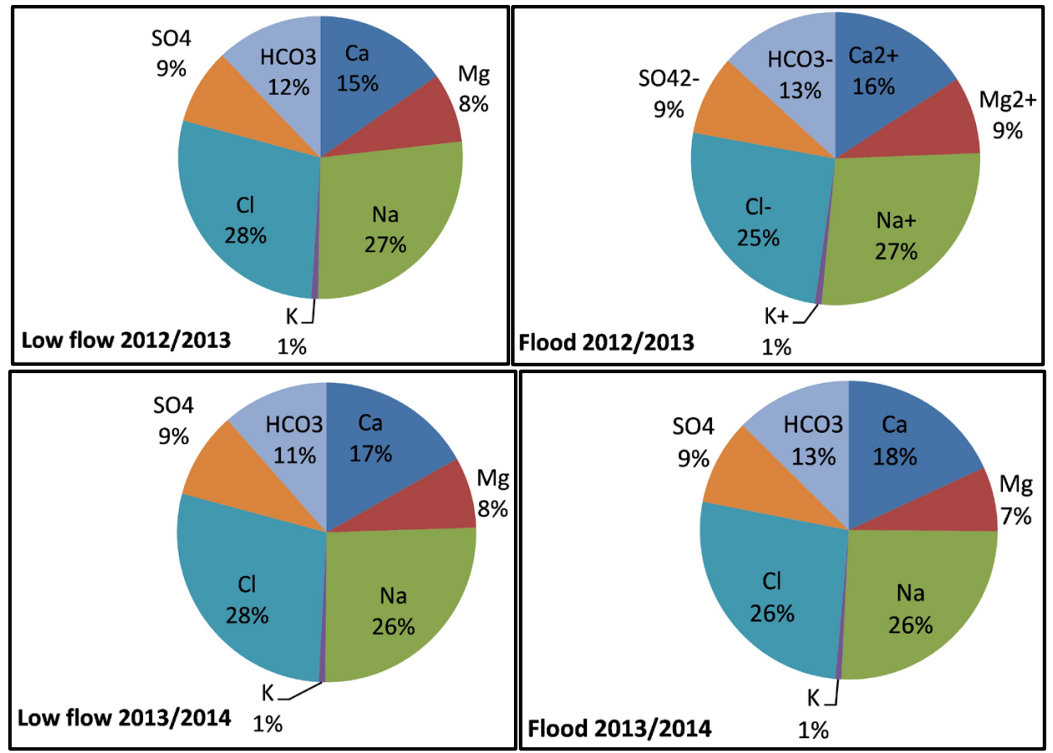

Figure 2. Proportions of the main cations and anions (meq/l) during the two sampling years 2012/2013 and 2013/2014.

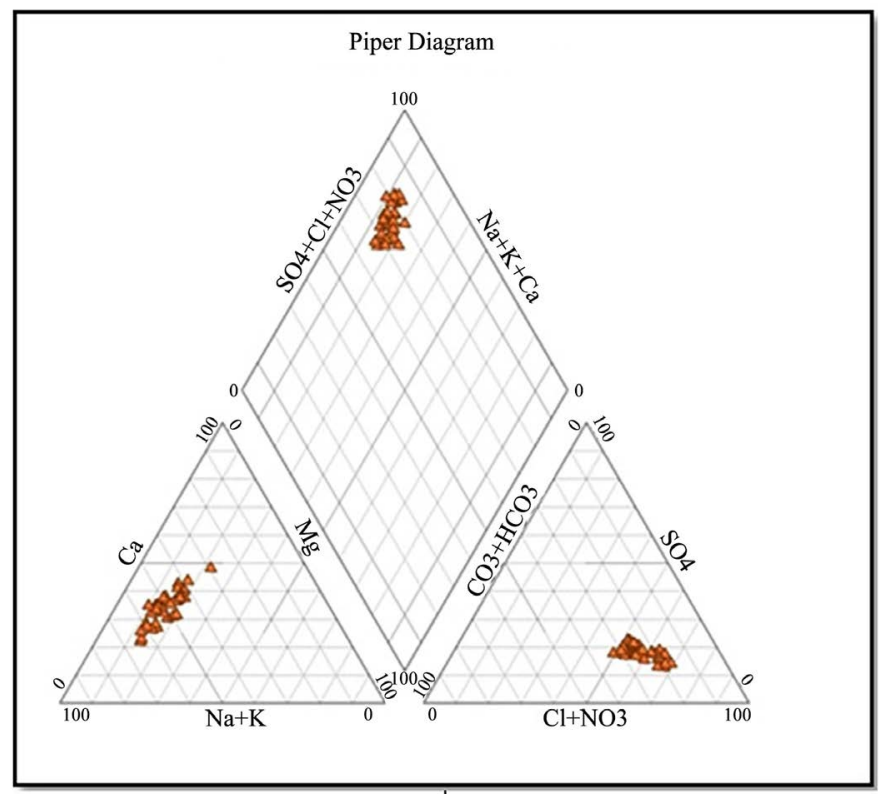

Figure 3. Piper diagram, in equivalent, for the main cations and anions of Mechra Bel Ksiri waters for the 2012/2014 sampling period.

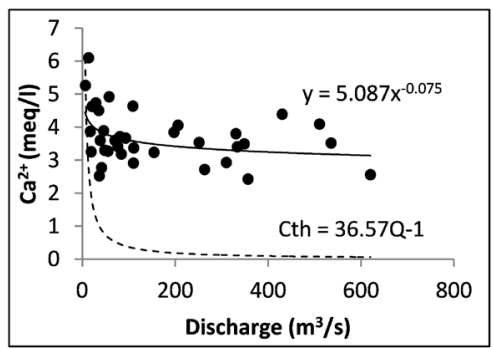

(a)

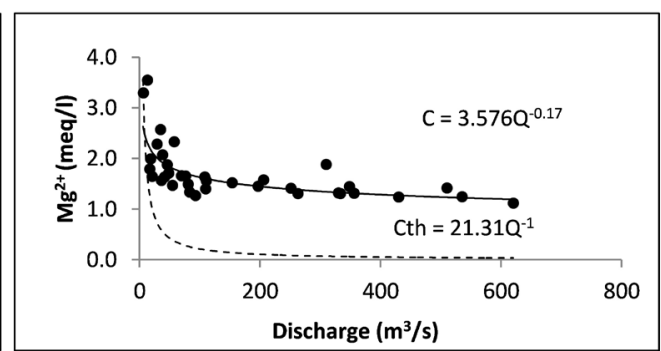

(b) 


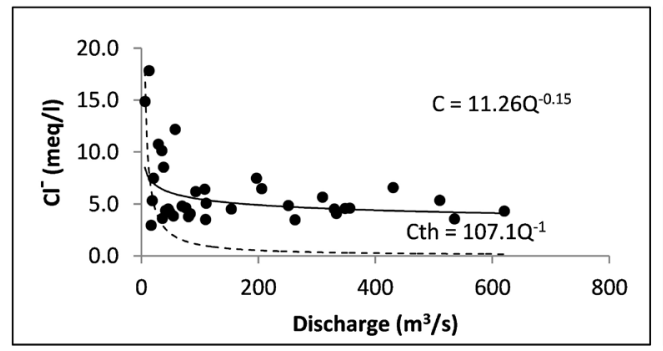

(c)

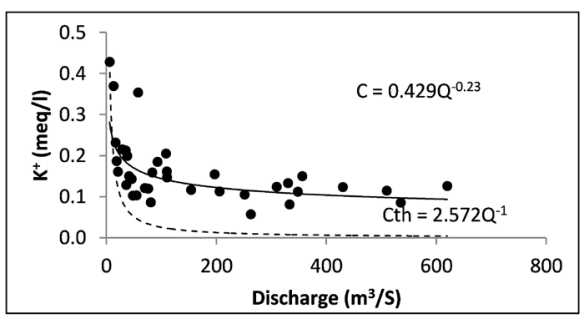

(e)

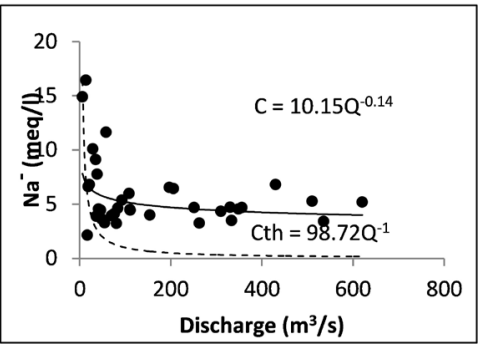

(d)

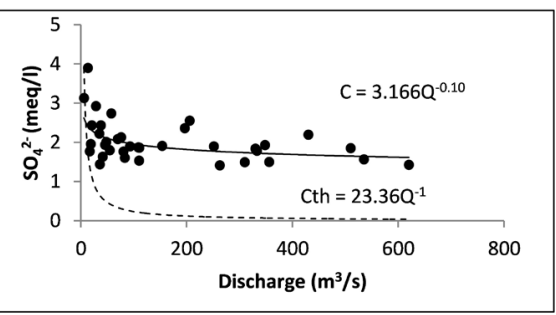

(f)

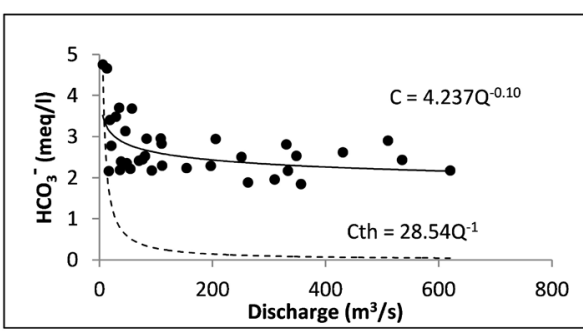

(g)

Figure 4. Evolution of the main dissolved major elements as a function of the flow at the Mechra Bel Ksiri station for the years 2012/2014.

The comparison between the curves representing the flow-concentration relationship (solid line) and the theoretical dilution curve (dashed lines) reveals that during periods of low water (low water), there is a high concentration of chemical elements, and that as the flow rates increases the concentrations decreases but remain higher than the values corresponding to the theoretical dilution curve. The concentrations for the theoretical dilution curve tends to approach zero, while the concentrations for the flow-concentration curves of the different chemical elements of the river water decreases but deviates significantly and remains above the theoretical dilution curve. The comparison of the theoretical dilution curves and the flow-concentration curves reveals the contribution of two sources of inputs of chemical elements: groundwater during periods of low water and runoff water during high-water periods. The $\mathrm{Na}^{+}$and $\mathrm{Cl}^{-}$and $\mathrm{K}^{+}$elements are well connected to the flows, they have a very marked deviation of the concentrations during the high-water period.

\subsection{Origin of Dissolved Elements}

The complex interactions between the lithosphere, the atmosphere, the hydrosphere and the biosphere constitute the factors governing chemical weathering 
(Chetsworth, 1992) [28]. On the other hand, these factors controlling chemical weathering processes are difficult to quantify.

The chemical composition of suspended matter carried by river waters reflects the lithological nature of the rocks and soils of the drainage catchments. The correlations between the different chemical elements (Figure 5), made it possible to highlight the influence of the lithology which is one of the main factors of control of the chemical composition of the waters, to determine other sources of contribution.

Thus, from the correlations (Table 2) between the chemical elements of the different periods, it is possible to determine the influence of the lithology, see the different contributions of the chemical elements.

The correlation between Sodium and chloride (Figure 5(a)) shows points that coincide with the slope line 1 characteristic of evaporites. The correlation coefficient is very high with $\mathrm{R}^{2}=0.966$, it can be deduced that the majority of $\mathrm{NaCl}$ comes from halite. The correlation between calcium and sulphate (Figure 5(b)) is characterized by a ratio that is greater than 1 . The points are above the slope line 1 characteristic of gypsum. It can probably be deduced that the $\mathrm{Ca}^{2+}$ contribution of gypsum in Sebou waters is low. The correlation of $\mathrm{Ca}^{2+}$ and $\mathrm{HCO}_{3}^{-}$ (Figure 5(c)) shows very similar points on the slope curve 1 characteristic of carbonates, the contribution of $\mathrm{Ca}^{2+}$ and $\mathrm{HCO}_{3}^{-}$probably comes mostly from alteration of carbonates mainly from calcite contained in rocks. The representation of the content of $\mathrm{Ca}^{2+} \mathrm{Mg}^{2+}$ as a function of $\mathrm{SO}_{4}^{2-}+\mathrm{HCO}_{3}^{-}$(Figure 5(d), Equation (5)) shows that the points are distributed around the slope line 1, which suggests that the main geochemical phenomena involved are probably related to the water-rock interaction (dissolution and precipitation of minerals: calcite, dolomite, gypsum).

\subsection{Demonstration of the Mineralization of the Waters}

On the basis of the thermodynamic equilibrium, it is possible to define a chemical evolution of Sebou water in Mechra Bel Ksiri; as a result the trend of the chemical forms between the dissolved phase and the mineral phase was realized.

The dissolution of a mineral in water can be described by a state of equilibrium. When the water is in contact with a mineral, the concentration of the solution increases to reach a maximum for given physicochemical conditions. It is said that the solution is saturated with this mineral.

The saturation index expresses the degree of chemical equilibrium between water and the mineral in the rock and can be considered as a measure of the dissolution and/or precipitation process concerning the water-rock interaction. Saturation indices for minerals (halite, gypsum, sylvite, calcite, dolomite and aragonite) and chemical equilibria were calculated using the PhreeqC program, which allows chemical alteration simulations much closer to natural conditions (PARKHURST et al., 1999). 
Table 2. Reactions to predicted dominant alterations in the Sebou River Basin, based on the relative alteration rates of dominant minerals.

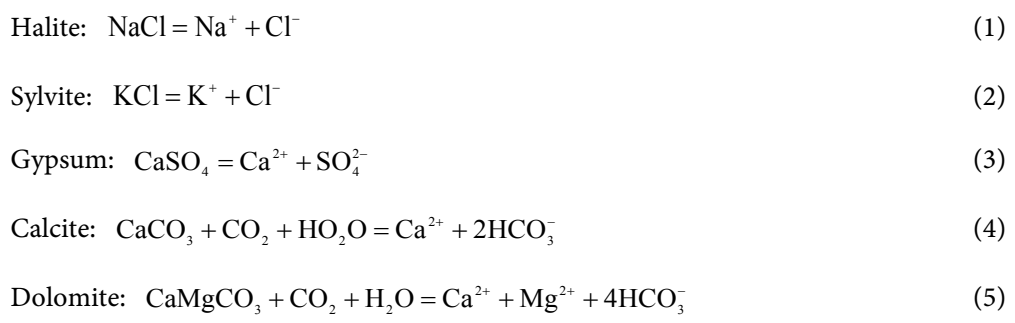

Sylvite: $\mathrm{KCl}=\mathrm{K}^{+}+\mathrm{Cl}^{-}$

Gypsum: $\mathrm{CaSO}_{4}=\mathrm{Ca}^{2+}+\mathrm{SO}_{4}^{2-}$

Calcite: $\mathrm{CaCO}_{3}+\mathrm{CO}_{2}+\mathrm{HO}_{2} \mathrm{O}=\mathrm{Ca}^{2+}+2 \mathrm{HCO}_{3}^{-}$

Dolomite: $\mathrm{CaMgCO}_{3}+\mathrm{CO}_{2}+\mathrm{H}_{2} \mathrm{O}=\mathrm{Ca}^{2+}+\mathrm{Mg}^{2+}+4 \mathrm{HCO}_{3}^{-}$
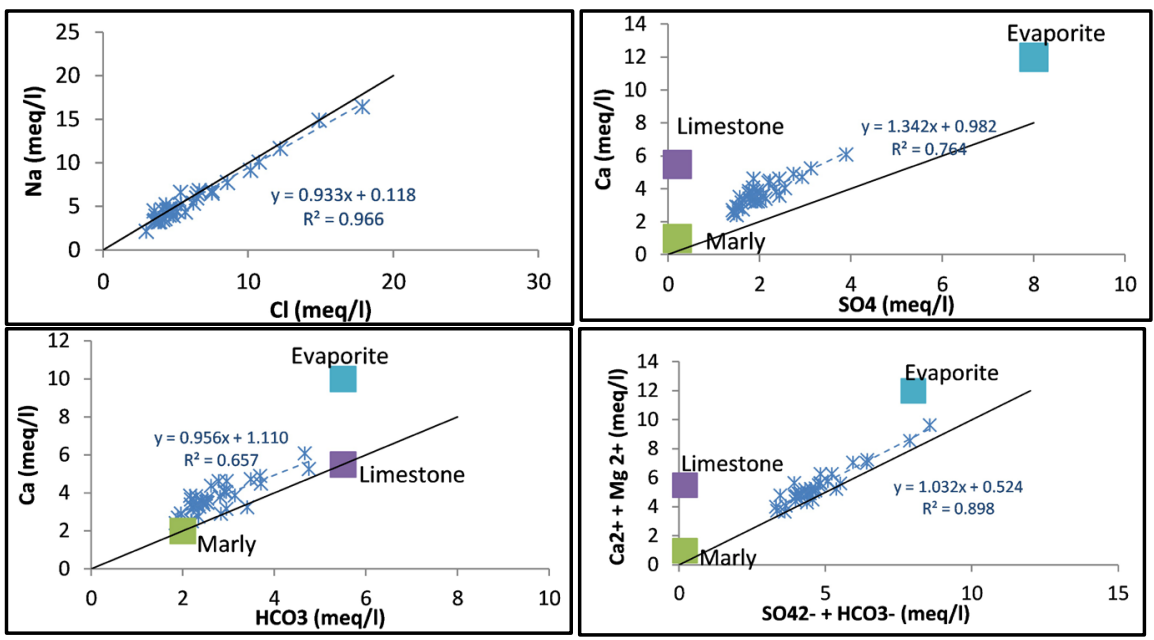

Figure 5. Relationship between the levels of cations and anions of Sebou water in Mechra Bel Ksiri during the years 2012/2014.

The average values of the water saturation indices in relation to the minerals at Mechra Bel Ksiri (Table 3, Figure 6) for the years 2012/2013 and 2013/2014, indicate that the saturation levels of the water ranges from saturated to supersaturated with calcite, dolomite and aragonite. Precipitation of calcite, dolomite and aragonite occurs when their saturation indices are greater than 1 (Kazmeierczak and Kemp 1990; Zaihua et al., 1995) [29] [30]. The saturation indices of calcite, dolomite and aragonite vary between -0.5 and 2.5 , but there is a supersaturation of dolomite with respect to the other two minerals, with saturation indices of dolomite which are twice that of calcite and aragonite.

On the other hand, there is rather under saturation of the water vis-à-vis the minerals of halite, gypsum and sylvite, their indices of saturation vary between -8 and -1 . These minerals are dissolved and strongly contribute to the supply of $\mathrm{Na}$ and $\mathrm{Cl}$ in the water.

Figure 7 shows the correlations between the water saturation indices vis-à-vis the minerals with regards to the cationic charge. There is a strong correlation between the halite and sylvite minerals with regards to the cationic charge, with $\mathrm{R}^{2}=0.817$ for halite and $\mathrm{R}^{2}=0.760$ for sylvite, and a mean gypsum correlation and cationic charge $\mathrm{R}^{2}=0.517$. This would probably mean that the majority of 
$\mathrm{Na}^{+}, \mathrm{Cl}^{-}, \mathrm{K}^{+}$and $\mathrm{SO}_{4}^{2-}$ ions would come from the dissolution of evaporites. Unlike evaporites, for carbonate (Calcite, dolomite and aragonite) there is a strong dispersion of points around the correlation line.

Table 3. Degree of saturation of the waters of Mechra Bel Ksiri vis-à-vis minerals during the 2012/2013 and 2013/2014 hydrological cycles.

\begin{tabular}{ccccc}
\hline Parameter & Average & Minimum & Maximum & standard deviation \\
\hline Aragonite & 0.43 & -0.16 & 1.18 & 0.37 \\
Calcite & 0.58 & -0.01 & 1.32 & 0.36 \\
Dolomite & 0.85 & -0.37 & 2.47 & 0.83 \\
Gypsium & -1.70 & -1.99 & -1.38 & 0.15 \\
Halite & -6.15 & -6.78 & -5.21 & 0.37 \\
Sylvite & -7 & -7.61 & -6.18 & 0.36 \\
\hline
\end{tabular}

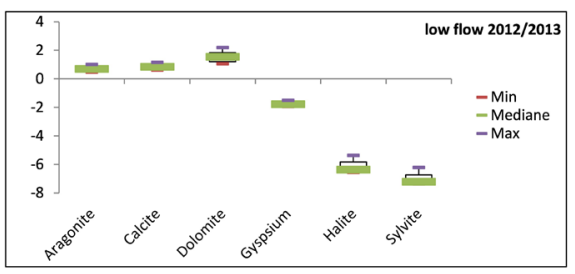

(a)

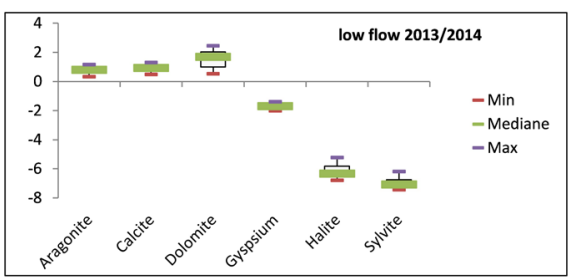

(c)

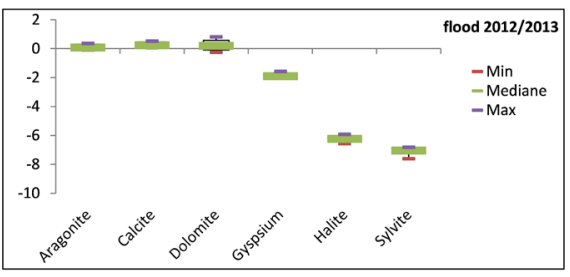

(b)

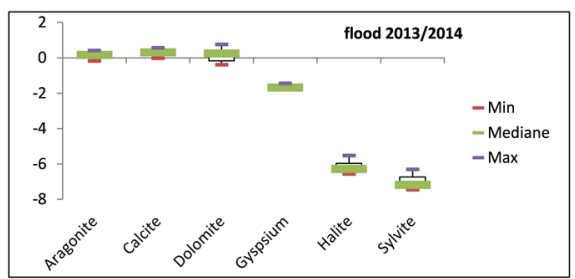

(d)

Figure 6. Mustache boxes of the saturation indices of Aragonite, Calcite, Dolomite, Gypsum, Halite, Sylvite water at the station Mechra Bel Ksiri during hydrological cycles 2012/2013 and 2013/2014.
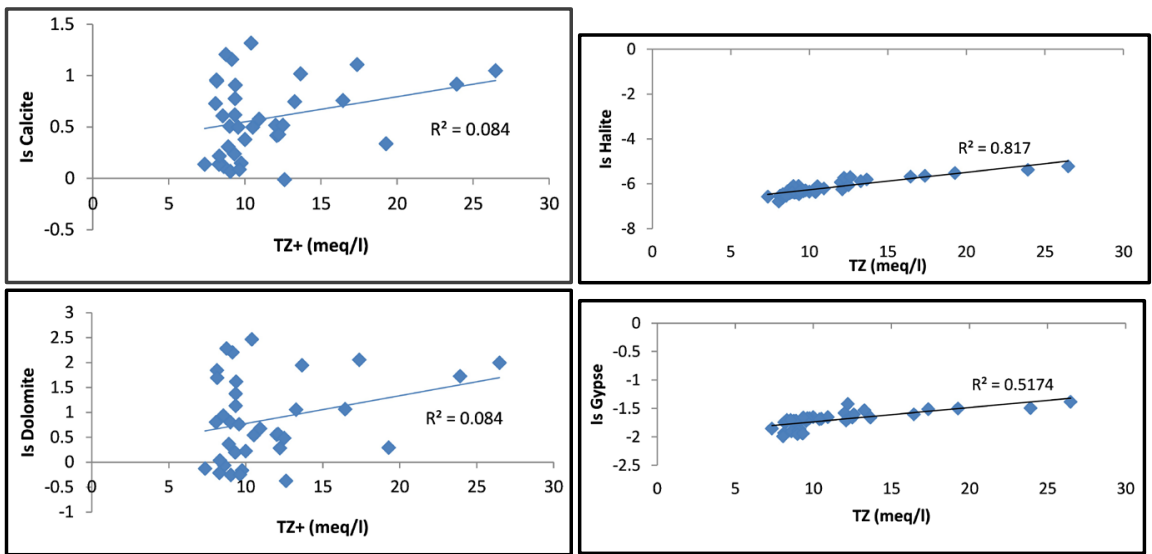


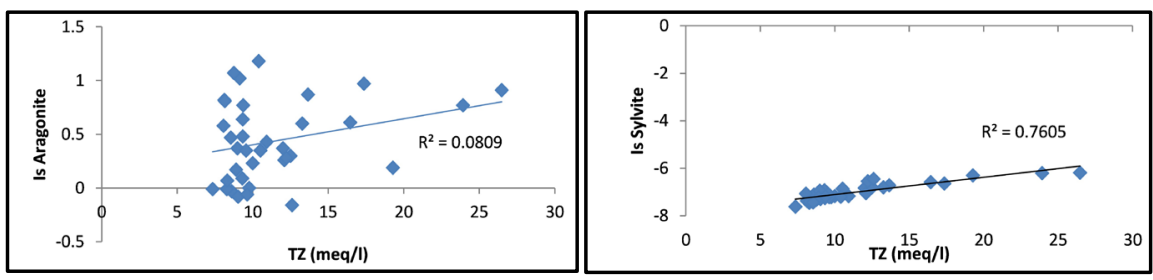

Figure 7. Saturation index relation compared to the minerals with the cationic charge $(\mathrm{TZ}+)$ of the waters of Sebou to Mechra Bel Ksiri during the hydrological cycles of $2012 / 2013$ and $2013 / 2014$.

\subsection{Geochemical Assessment of the Water at Mechra Bel Ksiri Downstream from the Sebou Basin}

4.6.1. Assessment of Concentration or Dilution of the Major Chemical Elements Dissolved in the Waters of the Sebou at Mechra Bel Ksiri

The concentration and dilution factors of the major elements (Table 4) show a greater or lesser concentration of the $\mathrm{Ca}^{2+}$ and $\mathrm{HCO}_{3}^{-}$ions in the flood, when the $\mathrm{Cl}^{-}$and $\mathrm{Na}^{+}$are rather diluted. The period of 1962/70 representing the wet period shows the highest concentration values of $\mathrm{Ca}^{2+}$ and $\mathrm{HCO}_{3}^{-}$with respectively 4.5 and 3.5. The dry period that followed and started in 1979 shows decreasing values of the $\mathrm{rN}$ ratio not exceeding 1.38 and showing a decrease in the levels of $\mathrm{Ca}^{2+}$ and $\mathrm{HCO}_{3}^{-}$at low water levels. The hydrological years 2012/2013 and 2013/2014 are quite similar to the years of the dry period with $\mathrm{rN}$ ratios varying between 1 and 1.30 for $\mathrm{Ca}^{2+}$ and $\mathrm{HCO}_{3}^{-}$. The reduction in $\mathrm{Ca}^{2+}$ and $\mathrm{HCO}_{3}^{-}$during the low-water period can be attributed to a precipitation of calcium carbonates in the alluvial plain in accordance with the process called " $\mathrm{Ca}^{2+}$ dynamics" by soil scientists in vertisols (Bryssine, 1968) [31]. $\mathrm{Cl}^{-}$and $\mathrm{Na}^{+}$remain diluted for any hydrological period.

\subsubsection{Flow of Major Elements}

The flow of suspended matter from a watercourse is defined as the amount of SS mass transiting through this section for one unit of time (Vanoni, 1975; Droux et al., 2003) [32] [33]. Indeed the surface of the continents is continually attacked by rainwater through two major and competitive geodynamic processes. Chemical alteration partially dissolves continental rocks to form soils, then these soils and their "mother rocks" are physically attacked by mechanical erosion. The products that result from these erosion and weathering processes are carried by the rivers and are the main stream of materials that feed the oceans.

The balance of the main elements in solution exported by Sebou to Mechra Bel ksiri is calculated for the hydrological cycles 2012/2013 and 2013/2014. During the two cycles studied, the Sebou exported on average 333.4 tonnes of elements in solution, i.e. a specific transport of $127.33 \mathrm{t} / \mathrm{km}^{2} /$ year. In this transport of material, it is mainly floods that are responsible for most of these inputs (82\%) (Figure 8). The magnitude of the variations in liquid flows between floods and low flows $\left(\mathrm{Q}_{\text {flood }} / \mathrm{Q}_{\text {low flow }}=5.48\right)$ is moderately higher than that of the variations of the exported dissolved fluxes $\left(\Phi_{\text {flood }} / \Phi_{\text {low flow }}=4.6\right)$. 
Table 5 shows that the quantity of chloride exported to Mechra Bel Ksiri during the hydrological cycles is on average $101,4.10^{4}$ tonnes, is $30 \%$ of total transport in solution. The tonnages of bicarbonates, sodium and sulphates are also high, accounting respectively for $23 \%, 19 \%$ and $14 \%$ of total transport. The four elements $\mathrm{Cl}^{-}, \mathrm{HCO}_{3}^{-}, \mathrm{Na}^{+}$and $\mathrm{SO}_{4}^{2-}$ are thus responsible for $86 \%$ of the transport in solution downstream from Sebou to Mechra Bel Ksiri. The calcium flux represents $10 \%$ of the total dissolved intake.

The comparison of the dissolved specific transport at Mechra Bel ksiri between the 1996/1998 (Haida, 2000) and 2012/2014 (Table 6) hydrological cycles shows a $23.6 \%$ decrease in dissolved transport downstream of the Sebou basin. The specific tonnage increases from $167 \mathrm{t} / \mathrm{km}^{2} /$ year to $127.6 \mathrm{t} / \mathrm{km}^{2} /$ year. In general, these contributions in solution are mainly controlled by natural factors: lithology, relief and climate (Meybeck, 1984; Bluth and Kump, 1994) [34] [35] and anthropogenic factors. This decrease in dissolved transport can be attributed to the decrease in flows brought downstream of the basin and also to the upstream water management by the various dams built.

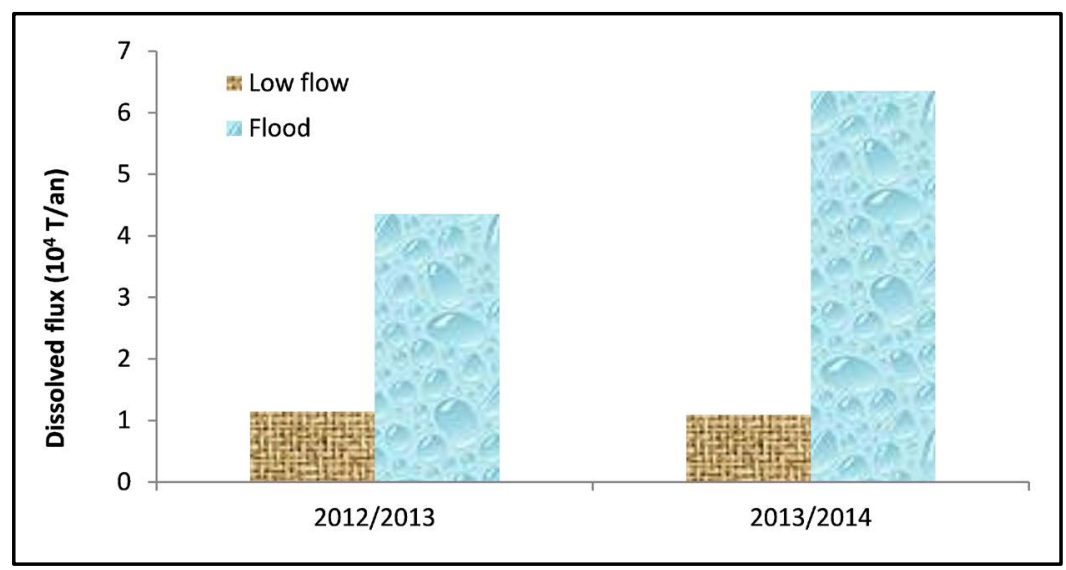

Figure 8. Seasonal variations of the dissolved flows downstream from Sebou to Mechra Bel Ksiri during the 2012-2014 hydrological cycles.

Table 4. Concentration or dilution factor of the different dissolved chemical elements downstream of the Sebou for the different hydrological periods 1962/70, 1993/95 1996/1998 (Haida, 2000) and 2012/2013 and 2013/2014.

\begin{tabular}{cccccccc}
\hline & $\mathrm{rCa}^{2+}$ & $\mathrm{rMg}^{2+}$ & $\mathrm{rNa}^{+}$ & $\mathrm{rK}^{+}$ & $\mathrm{rCl}^{-}$ & $\mathrm{r} \mathrm{SO}_{4}^{2-}$ & $\mathrm{HCO}_{3}^{-}$ \\
\hline $1962 / 70$ & 4.5 & 0.81 & 0.63 & 1 & 0.62 & 0.9 & 3.5 \\
$1993 / 95$ & 1.38 & 1.25 & 0.76 & 1 & 0.77 & 1.4 & 1.38 \\
$1996 / 97$ & 1.18 & 1 & 1 & 1 & 0.97 & 0.66 & 1.18 \\
$1997 / 98$ & 1.31 & 1 & 0.86 & 1 & 0.87 & 1.12 & 1.27 \\
$2012 / 13$ & 1.06 & 0.94 & 1 & 1 & 0.96 & 1.04 & 1.19 \\
$2013 / 14$ & 1.20 & 0.97 & 0.92 & 1 & 0.88 & 1.10 & 1.29 \\
\hline
\end{tabular}


Table 5. Mean chemical composition of the dissolved major elements, the dissolved flux and the specific flow of elements brought by the Sebou stream downstream to Mechra Bel Ksiri during the hydrological cycles 1962/70, 1993/95 1996/1998 (Haida, 2000) and $2012 / 2013$ and $2013 / 2014$.

\begin{tabular}{|c|c|c|c|c|c|c|c|}
\hline \multirow{2}{*}{\multicolumn{2}{|c|}{$\begin{array}{c}\text { Flux of major } \\
\text { elements }\end{array}$}} & \multicolumn{3}{|c|}{$2012 / 2013$} & \multicolumn{3}{|c|}{$2013 / 2014$} \\
\hline & & $\begin{array}{l}\text { Concentration } \\
(\mathrm{mg} / \mathrm{l})\end{array}$ & $\begin{array}{l}\text { Dissolved } \\
\text { flux } \\
\text { (Tonnes) }\end{array}$ & $\begin{array}{l}\text { Specific flux } \\
\left(\mathrm{T} / \mathrm{km}^{2} / \text { year }\right)\end{array}$ & $\begin{array}{c}\text { Concentration } \\
(\mathrm{mg} / \mathrm{l})\end{array}$ & $\begin{array}{l}\text { Dissolved } \\
\text { flux } \\
\text { (Tonnes) }\end{array}$ & $\begin{array}{l}\text { Specific flux } \\
\left(\mathrm{T} / \mathrm{km}^{2} / \text { year }\right)\end{array}$ \\
\hline \multirow{7}{*}{$\begin{array}{l}\text { Sebou at } \\
\text { Mechra } \\
\text { Bel Ksiri }\end{array}$} & $\mathrm{Ca}^{2+}$ & 65.03 & $28.5 \times 10^{4}$ & 10.9 & 78.97 & $39.7 \times 10^{4}$ & 15.17 \\
\hline & $\mathrm{Mg}^{2-}$ & 21.10 & $9.3 \times 10^{4}$ & 3.56 & 20.57 & $10.3 \times 10^{4}$ & 3.97 \\
\hline & $\mathrm{Na}^{+}$ & 135.55 & $59.1 \times 10^{4}$ & 22.6 & 132.99 & $66.2 \times 10^{4}$ & 25.28 \\
\hline & $\mathrm{K}^{+}$ & 6.51 & $2.8 \times 10^{4}$ & 1.1 & 6.15 & $3 \times 10^{4}$ & 1.17 \\
\hline & $\mathrm{Cl}^{-}$ & 208.5 & $91.6 \times 10^{4}$ & 34.9 & 221.82 & $111.2 \times 10^{4}$ & 42.44 \\
\hline & $\mathrm{SO}_{4}^{-}$ & 88.06 & $38.5 \times 10^{4}$ & 14.72 & 102.13 & $51.8 \times 10^{4}$ & 19.8 \\
\hline & $\mathrm{HCO}_{3}^{-}$ & 163.41 & $71.8 \times 10^{4}$ & 27.4 & 165.77 & $83 \times 10^{4}$ & 31.65 \\
\hline
\end{tabular}

Table 6. Specific dissolved fluxes of major elements measured downstream of Sebou between the 1996/1998 (Haida, 2000) and 2012/2014 hydrological cycles.

\begin{tabular}{ccc}
\hline & \multicolumn{2}{c}{ Specific dissolved fluxes $\left(\mathrm{t} / \mathrm{km}^{2} /\right.$ year $)$ at Mechra Bel Ksiri } \\
\cline { 2 - 3 } & $1996-1998$ & $2012-2014$ \\
\hline $\mathrm{Ca}^{2+}$ & 14.5 & 13 \\
$\mathrm{Mg}^{2-}$ & 5 & 3.76 \\
$\mathrm{Na}^{+}$ & 32 & 24 \\
$\mathrm{~K}^{+}$ & 0.7 & 1.4 \\
$\mathrm{Cl}^{-}$ & 53 & 38.67 \\
$\mathrm{SO}_{4}^{-}$ & 18 & 17.26 \\
$\mathrm{HCO}_{3}^{-}$ & 40.6 & 29.52 \\
$\mathrm{Total}^{-}$ & 167 & 127.6 \\
\hline
\end{tabular}

\section{Conclusions}

The chemical composition of the waters downstream of Sebou shows very high dissolved loads ranging between $400 \mathrm{mg} / \mathrm{l}$ and $1400 \mathrm{mg} / \mathrm{l}$, with predominant proportions of chlorides and sodium (52\%) making the waters of the wadi sodium-chloride facies, followed by calcium (18\%), bicarbonates (13\%) and sulphates (9\%).

The evolution of the concentrations of the chemical elements measured during the hydrological cycles 2012/2013 and 2013/2014 showed a decrease in concentrations during the high-water period and the opposite during the period of low water, with a marked decrease in period of high water for $\mathrm{Na}^{+}, \mathrm{Cl}^{-}$and $\mathrm{K}^{+}$. This behavior is attributed to a dilution of river waters more concentrated in chemical elements by much less concentrated meteoric waters. The "flow-concentrations" relationships enabled us to identify the deep or superficial origin of the different chemical elements measured in solution in the water, with either a chemical element input of the highly concentrated groundwater during periods of low water, or a contribution of dissolved element by the superficial waters through the leaching of soils. Concentration or dilution factors showed 
that concentrations of chemical elements decreased significantly between the wet period and the dry period for $\mathrm{Ca}^{2+}$ and $\mathrm{HCO}_{3}^{-}$from 4.5 and 3.5 to below the two elements, while the $\mathrm{Na}^{+}$and $\mathrm{Cl}^{-}$remained diluted regardless of the hydrological period.

The annual tonnage of materials exported during the study period shows that the total mass of dissolved elements exported by the waters downstream of Sebou to Mechra Bel Ksiri is dominated by $53 \%$ chloride and sodium, while $82 \%$ of the total material transported to the oceans is during periods of high water. The analysis of the fluxes calculated for the different elements can lead us to say that the main origin of chloride and sodium is the leaching of soils. This high tonnage of chloride and sodium can be attributed to the lithology which is characterized by an abundance of evaporitic and carbonate rocks with the influence of irregular hydrological regimes.

\section{References}

[1] Livingstone, D.A. (1963) Chemical Composition of Rivers and Lakes. Data of Geochemistry. US Geol Survey Prof. Paper 440 G, G1-G64.

[2] Meybeck, M. (1976) Total Dissolved Salts of the World's Largest Rivers. Hydrological Sciences Bulletin, 21, 265-284. https://doi.org/10.1080/02626667609491631

[3] Berner, E.K. and Berner, R.A. (1996) Water, Air and Geochemical Cycles. 2nd Edition, Global Environment.

[4] Jickells, T.D. (1998) Nutrient Biogeochemistry of the Coastal Zone. Science, 10, 217-222. https://doi.org/10.1126/science.281.5374.217

[5] Holland, H.D. (2005) Sea Level, Sediments and the Composition of Seawater. American Journal of Science, 305, 220-239. https://doi.org/10.2475/ajs.305.3.220

[6] Corbonnois, J. (1996) The Factors of the Spatio-Temporal Variation of Solid and Dissolved Transports. Example of Three Watersheds in Lorraine. Geomorphology: Relief, Process, Environment. Flight, 4, 313-329.

[7] Dupraz, Ch. (1984) Summary of Transfers of Water and Mineral Elements in Three Contrasting Contrasting Basins (Mont Lozère, France). Thesis, University of Orleans, Orleans, $363 \mathrm{p}$.

[8] Meybeck, M. (1985) Variability in Time of the Chemical Composition of Rivers and Their Transport in Solution and in Suspension. Journal of Water Science, 4, 93-121.

[9] Kattan, Z. (1989) Geochemistry and Hydrology of Fluvial Waters of the Moselle and Mossig Basins, Dissolved and Particulate Transport, Biogeochemical Cycle of the Elements. Thesis, Louis Pasteur University of Strasbourg, Strasbourg, 167 p.

[10] Bakalowicz, M. (1995) The Infiltration Zone of Karst Aquifers. Study Method. Structure and Operation. Hydrogeology, 4, 3-21.

[11] Haida, S. (2000) Material Transport and Assessment of Mechanical Erosion and Chemical Alteration in a Semi-Arid Catchment Area: Sebou. Doctoral Thesis Es-Sciences, University Ibn Tofail, Faculty of Sciences, Kenitra, 253 p.

[12] ABHS (2011) Study to Update Master Plan for Integrated Management of Water Resources in the Sebou Basin, Report PDAIRE.

[13] Combe, M. (1969) Hydrogeological Map of the Rharb Plain at 1/100000. Notes and Memoirs. Morocco Geological Service, Rabat, No. 221 BIS. 
[14] Combe, M. (1975) Water Resources of Morocco, Plains and Watersheds of Morocco: The Rharb-Maamora Basin. Notes and Memoirs. Morocco Geolocal Service, Rabat, No. 231, t. 2, 3-128.

[15] ORMVAG (1997) Environmental Impact Study: Development Studies of the T.T.I of Rharb (Z3/Z4-Mograne). Unpublished Report, $180 \mathrm{p}$.

[16] Cidu, R., Biddau, R. and Fanfani, L. (2009) Impact of Past Mining Activity on the Quality of Groundwater in SW Sardinia (Italy). Journal of Geochemical Exploration, 100, 125-132. https://doi.org/10.1016/j.gexplo.2008.02.003

[17] Parkhurst, D.L. and Appelo, C.A.J. (1999) User's Guide to PHREEQC (Version 2): A Computer Program for Speciation, Batch Reaction, One Dimensional Transport, and Inverse Geochemical Calculations. US Geol. Surv. Water Resource Invest. Rep 99-4259.

[18] Manczak, H. and Florckzyk, H. (1971) Interpretation of Results from Studies of Pollution of Surface Flowing Waters. Water Resources Research, 5, 575-584. https://doi.org/10.1016/0043-1354(71)90113-8

[19] Probst, J.L. (1983) Hydrology of the Garonne Basin. Mixture Pattern. Assessment of Erosion. Export of Phosphates and Nitrates. 3rd Cycle Thesis, University of Toulouse, Toulouse, $148 \mathrm{p}$.

[20] Meybeck, M. (1979) Concentration of Fluvial Waters in Major Elements and Solutions in Solution to the Oceans. Journal of Physical Geography and Dynamic Geology, 3, 215-246.

[21] Stallard, R.F. and Edmond, J.M. (1983) Geochemistry of the Amazon/2. The Influence of Geology and Weathering Environment on the Dissolved Load. Journal of Geophysical Research, 88, 9671-9688. https://doi.org/10.1029/JC088iC14p09671

[22] Probst, J.L. (1990) Geochemistry and Hydrology of Continental Erosion. Mechanisms, Current Global Balance and Fluctuations over the Last 500 Million Years. State Thesis, Sci., Geol., Univ., Strasbourg, 190 p.

[23] Amiotte-Suchet, P. (1995) Carbon Cycle, Chemical Erosion of Continents and Transfer to the Oceans. Same. Sci. Geol., Strasbourg, No. 97, 156.

[24] Goldstein, S.J. and Jacobsen, S.B. (1987) ThNdansSr Isotopic Systematic of River Water Dissolved Material: Implication for the Sources of $\mathrm{Nd}$ and $\mathrm{Sr}$ in Seawater. Chemical Geology, 66, 245-272. https://doi.org/10.1016/0168-9622(87)90045-5

[25] Negrel, P., Allegre, C.J., Dupre, B. and Lewin, E. (1993) Erosion Sources Determined by Inversion of Major and Trace Element Ratios and Strontium Isotopic Ratios in River Water: The Congo Basin Case. Earth and Planetary Sciences Letters, No. 120, 59-76. https://doi.org/10.1016/0012-821X(93)90023-3

[26] Semhi, K. (1996) Erosion and Transfer of Materials in the Garonne Catchment Area. Influence of Drought. Thesis, Doc. Univ., Strasbourg, 203 p.

[27] Bahin, Y.B.E., Haida, S. and Probst, J.-L. (2017) Analysis of the Hydroclimatic Variability and Impact of Dams on the Hydrological Regime of a Semi-Arid River: Sebou in Morocco. European Scientific Journal, 13, 509-525. https://doi.org/10.19044/esj.2017.v13n5p509

[28] Chesworth, W. (1992) Weathering Systems. In: Martini and Chesworth, Eds., Weathering, Soil and Paleosols, Elsevier, Amsterdam, 19-40. https://doi.org/10.1016/B978-0-444-89198-3.50007-6

[29] Kazmeierczak, J. and Kemp, S. (1990) Modern Cyanobacterial Analyzes of Paleozoic Stromatoporoids. Revolutionary Science, 250, 1244-1248. 
[30] Zaihua, L., Svensson, W., Dreybrodt, W., Daoxian, Y. and Buhmann, D. (1995) Hydrodynamics Control of Inorganic Calcite Precipitation in Huanglon Ravine, China: Field Measurements and Theoretical Prediction of Deposition Rates. Geochimica et Cosmochimica Acta, 50, 3087-3097. https://doi.org/10.1016/0016-7037(95)00198-9

[31] Bryssine, G. (1968) Contribution to the Study of Limestone in Moroccan Soils: I. Research on Coarse Limestone in Clay Soils of Rharb. Al Awamia, No. 26, 97-147.

[32] Vanoni V.A. (1975) Sedimentation Engineering Practice. American Society of Civil Engineers, Manuals and Reports on Engineering Practice, No. 54, 745 p.

[33] Droux, J.P., Mietton, M. and Olivry, J.C. (2003) Suspended Particulate Matter Fluxes in the Sudanian Savanna Zone: The Example of Three Malian Watersheds. Geomorphology: Relief, Process, Environment, 9, 99-110.

[34] Meybeck, M. (1984) Rivers and Geochemical Cycles of the Elements. State Thesis, No. 84, Univ. P. and M. Curie.

[35] Bluth, G.J.S. and Kump, L.R. (1994) Lithologic and Climatologic Controls of River Chemistry. Geochimica et Cosmochimica Acta, 58, 2341-2359.

https://doi.org/10.1016/0016-7037(94)90015-9 